\begin{tabular}{|c|c|c|c|c|c|c|c|c|c|c|c|}
\hline Species & $\begin{array}{l}\text { Grand } \\
\text { Total }\end{array}$ & $\begin{array}{l}\mathbf{Q u} \\
\mathbf{S W}\end{array}$ & $\stackrel{\text { derant }}{\text { NW }}$ & $\begin{array}{l}\text { Tot: } \\
\text { NE }\end{array}$ & SE & Species & $\begin{array}{l}\text { Grand } \\
\text { Total }\end{array}$ & & $\begin{array}{c}\text { adrant } \\
\text { NW }\end{array}$ & $\begin{array}{l}\text { Total } \\
\text { NE }\end{array}$ & SE \\
\hline Forst Tern & 1 & $\mathrm{x}$ & & & & Y-h Blkbird & 701 & $\mathrm{x}$ & $\mathrm{x}$ & $\mathrm{x}$ & $\mathrm{x}$ \\
\hline Common Tern & 6 & $\mathrm{x}$ & $\mathrm{x}$ & & & R-w Blkbird & $1,857+$ & $-x$ & $\mathrm{x}$ & $\mathrm{x}$ & $\mathrm{x}$ \\
\hline *Black Tern 1 & $1,785+$ & $x$ & $\mathrm{x}$ & $\mathrm{x}$ & $\mathrm{x}$ & Balt Oriole & 40 & $\mathrm{x}$ & $\mathrm{x}$ & $\mathrm{x}$ & $\mathrm{x}$ \\
\hline *Rock Dove & $120 \pm$ & $\mathrm{x}$ & $\mathrm{x}$ & $\mathrm{x}$ & $\mathrm{x}$ & Brwr Blkbird & $242+$ & $\mathrm{x}$ & $\mathrm{x}$ & $\mathrm{x}$ & $\mathrm{x}$ \\
\hline Mourning Dove & e $99 \overline{+}$ & $\mathrm{x}$ & $\mathrm{N}$ & $\mathrm{x}$ & $\mathrm{x}$ & Com Grackle & 25 & $\mathrm{x}$ & $\mathrm{x}$ & $\mathrm{x}$ & $\mathrm{x}$ \\
\hline $\mathrm{Gr} \mathrm{H} \mathrm{Owl}$ & 5 & & $\mathrm{x}$ & & $2 \mathrm{~N}$ & Br-h Cowbird & $202+$ & $-x$ & $\mathrm{x}$ & $\mathrm{x}$ & $\mathrm{x}$ \\
\hline Burrow Owl & 1 & & & & $\mathrm{x}$ & R-b Grsbeak & 4 & $\mathrm{x}$ & & $\mathrm{x}$ & \\
\hline Long-ear Owl & 1 & & $\mathbf{N}$ & & & Pine Siskin & 23 & $\mathrm{x}$ & $\mathrm{x}$ & & $\mathrm{x}$ \\
\hline Short-ear Owl & 1 & & $\mathrm{x}$ & & & Am Goldfinch & 60 & $\mathrm{x}$ & $\mathrm{x}$ & $\mathrm{x}$ & $\mathrm{x}$ \\
\hline R-th Humbird & 1 & & & $\mathrm{x}$ & & Ruf-s Towhee & 35 & $\mathrm{x}$ & $\mathrm{x}$ & $\mathrm{x}$ & $\mathrm{x}$ \\
\hline Y-sh Flicker & 45 & $\mathrm{x}$ & $\mathrm{x}$ & $\mathrm{x}$ & $\mathrm{x}$ & Lark Bunting & $210+$ & $\mathrm{x}$ & $\mathrm{x}$ & $\mathrm{x}$ & $\mathrm{x}$ \\
\hline Red-h Woodip & 1 & & & & $\mathrm{x}$ & Savan Sparrw & $75+$ & $\mathrm{x}$ & $\mathrm{x}$ & $\mathrm{x}$ & $\mathrm{x}$ \\
\hline Y-b Sapsucker & 1 & $\mathrm{x}$ & & & & Baird Sparrw & 17 & $\mathrm{x}$ & $\mathrm{x}$ & $\mathrm{x}$ & $\mathrm{x}$ \\
\hline Hairy Woodp & 6 & $\mathrm{x}$ & $\mathrm{x}$ & & $\mathrm{x}$ & LeCnt Sparrw & 4 & & & & $\mathrm{x}$ \\
\hline Downy Woodp & 4 & $\mathrm{x}$ & & & $\mathrm{x}$ & Vespr Sparrw & $145+$ & $-x$ & $2 \mathrm{~N}$ & $\mathrm{x}$ & $\mathrm{x}$ \\
\hline *E Kingbird & 95 & $\mathbf{x}$ & $\mathbf{x}$ & $\mathbf{x}$ & $\mathrm{x}$ & Lark Sparrw & 4 & $\mathrm{x}$ & $\mathrm{x}$ & & \\
\hline$*$ W Kingbird & 32 & $\mathrm{x}$ & $\mathrm{x}$ & $\mathrm{x}$ & $\mathrm{x}$ & Chip Sparrw & 10 & $\mathrm{x}$ & $\mathrm{x}$ & $\mathrm{x}$ & $\mathrm{x}$ \\
\hline E Phoebe & 2 & $\mathrm{x}$ & & & $\mathrm{x}$ & *Cl-col Sparrw & $327+$ & $\mathrm{x}$ & $\mathrm{x}$ & $\mathrm{x}$ & $\mathrm{x}$ \\
\hline Say's Phoebe & 1 & & & & $\mathrm{x}$ & Harris Sparrw & 1 & & & $\mathrm{x}$ & \\
\hline Lst Flycatch & $55+$ & $\mathrm{x}$ & $\mathrm{x}$ & $\mathrm{x}$ & $\mathrm{x}$ & Wh-cr Sparrw & 2 & $\mathrm{x}$ & & & \\
\hline W Wood Pewe & 1 & & & $\mathrm{x}$ & & Wh-th Sparrw & 2 & $\mathrm{x}$ & & & \\
\hline Horned Lark & $308+$ & $\mathrm{x}$ & $\mathrm{x}$ & $\mathrm{x}$ & $\mathrm{x}$ & Song Sparrw & $71 \pm$ & $\mathrm{x}$ & $\mathrm{x}$ & $\mathrm{x}$ & $\mathrm{x}$ \\
\hline Tree Swallow & $138+$ & $\mathrm{x}$ & $\mathrm{x}$ & $\mathrm{x}$ & $\mathrm{x}$ & McCown Lngsp & pr 5 & & & $\mathrm{x}$ & \\
\hline Bank Swallow & $433 \pm$ & $\mathrm{x}$ & $\mathrm{x}$ & $\mathrm{x}$ & $\mathrm{x}$ & Lplnd Longspr & 2 & & & $\mathrm{x}$ & \\
\hline Barn Swallow & $177 \overline{+}$ & $\mathrm{x}$ & $\mathrm{x}$ & $\mathrm{x}$ & $\mathrm{x}$ & C-col Lngspr & $96+$ & $\mathrm{x}$ & $\mathrm{x}$ & $\mathrm{x}$ & $\mathrm{x}$ \\
\hline Cliff Swallow & 7 & $\mathrm{x}$ & & & $\mathrm{x}$ & Snow Bunting & 1 & & & $\mathrm{x}$ & \\
\hline Purple Martin & 7 & & & & $\mathrm{x}$ & $\mathrm{N}$ indicates activ & ve nest & & & & \\
\hline Blue Jay & 2 & $\mathrm{x}$ & & & $\mathrm{x}$ & * Species for wh & hich to & tal & counts & & ere \\
\hline *B-b Magpie & 295 & $\mathrm{x}$ & $\mathrm{x}$ & $\mathrm{x}$ & $\mathrm{x}$ & requested. & & & & & \\
\hline *Common Crr & $618+$ & $\mathrm{x}$ & $3 N$ & $\mathrm{x}$ & $N$ & & & & & & \\
\hline
\end{tabular}

\title{
WHOOPING CRANE SURVIVAL
}

by F. G. Bard, Saskatchewan Museum of Natural History, Regina

Pessimists think that extinction of the Whooping Crane is but a matter of time. There can be little genetic variability in such a small population and the species will not be able to change with natural habitat changes. Others, however, hope that the population can be increased and they have taken action. For the second year eggs from nests in Wood Buffalo National Park have been flown to the Rare and Endangered Wildlife Research Center at Patuxent, Maryland. Since Whooping Cranes lay two egg's but rarely $\mathrm{x}$ raise more than one nestling this pro$\mathrm{x}$ ject has not reduced the number of young raised in the wild but it has allowed the building up of a captive $\mathrm{x}$ flock. Whoopers do not reach breeding $\mathrm{x}$ age until they are fiye years old. It is 
hoped that when captive birds start reproducing some young can be returned to the wild each year.

Increasing the size of the flock is, however, only one aspect of the problem. We must ensure that there will always be habitat for the Whooping Crane. In Canada wildlife habitat is rapidly dwindling and most Canadians are far too inclined to take wildlife and its habitats for granted. But good news comes from Ottawa where a strong national committee met in June under the sponsorship of the Department of Indian Affairs and Northern Development to establish sub-groups to assess unique land areas and to plan ways of preserving all kinds of habitat and wildlife. It is to be hoped that they will be able to preserve the nesting grounds of the Whooping Crane and prevent excessive pollution and human utilization of the area.

The biggest immediate problem in Whooping Crane survival, even surpassing all the perils of the long migration, is the threatened change to its wintering ground. We have just received word that the oyster shell dredgers have made application to dredge a total of 56 square miles of San Antonio Bay which runs the entire length of the eastern boundary of the Whooping Crane feeding grounds. Mud and silt will stay in suspension for a long period of time and the food chain of many species in this region will be affected. The changes may be disastrous to the welfare of wildlife in the Aransas Refuge and to the Whooping Crane in particular.

Canadian and American Wildlife Services are registering protests against the dredging plans. The application for dredging was made July 9 and deadline for protests is August 9. I received word, by telephone on July 25, from State Representative $\mathrm{H}$. Cory of Victoria, Texas. The mail strike in Canada has delayed and hampered communications but I hope that this wilderness area which is of international value and is a right of future generations will not be destroyed by the desires of one small group.

\section{AN EMPEROR GOOSE RECORD FOR BRITISH COLUMBIA}

by Al Grass, 5666 Rumble St., Burnaby, B.C.

Records for the Emperor Goose (Philacte canagica) in British Columbia are rather scarce. It is a pleasure therefore to report that one was observed and photographed by me on January 28, 1968 at the city of White

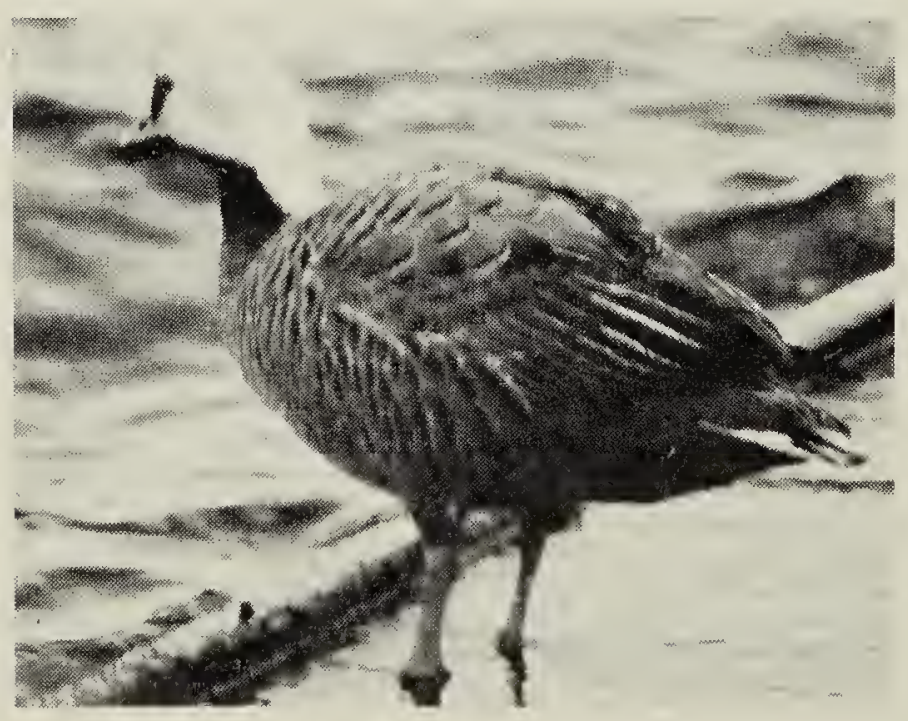

Rock. It was sitting on a floating jetty eating eel grass (Zostera marina) which had been washed up by the rather heavy waters which occurred during the week.

Godfrey (1966. The Birds of Canada, p. 51) gives the status of the bird as: "Rare winter visitant to the coast of British Columbia. Most frequently recorded from Masset, Queen Charlotte Islands, but has occurred also at Chemainus, Tlell, Cape Scott, Discovery Island, and Triple Island."

The bird was observed by a large number of people, including $\mathrm{Mr}$. Glen R. Ryder and Mr. C. Wavne Camnbell (who first alerted me to its presence). This species resembles the blue phase of the Snow Goose, but its black neck immediately separates it. 